\section{FOIA News}

The Faster FOIA Act of 2005, introduced by U.S. Senators John Cornyn and Patrick Leahy on March 10, would establish an advisory Commission on Freedom of Information Act Processing Delays. The commission would be charged with reporting to Congress and the President its recommendations for steps that should be taken to reduce delays in the administration of the Freedom of Information Act.

The commission would be comprised of 16 members; 12 of them would be appointed by members of Congress - three by the chairman of the Senate Judiciary Committee, three by the chairman of the House Government Reform Committee, and three each by the ranking minority member of the two committees. The four members of Congress would each be required to appoint at least one member to the commission with experience submitting FOIA requests on behalf of nonprofit research or educational organizations or news media organizations, and at least one member with experience in academic research in the fields of library science, information management, or public access to government information.

The remaining four positions on the commission would be held by designees of the attorney general, the director of the office of management and budget, the archivist of the United States, and the comptroller general.

The Faster FOIA Act is the latest in a series of bipartisan efforts by Senators Cornyn and Leahy to promote accountability, accessibility, and openness in our federal government. On February 16, the senators introduced the OPEN Government Act of 2005. And on the morning of March 15, during the first-ever national Sunshine Week, Senators Cornyn and Leahy convened a Senate Judiciary subcommittee hearing to examine both the OPEN Government Act and the Faster FOIA Act.

Bernadette Murphy is communications specialist at ALA's Washington Office, e-mail: bmurphy@alawash.org
In related FOIA news, Richard M. Schmidt, who devoted a long and illustrious career to the pursuit of open government and a free press, is the 2005 recipient of the Madison Award. Schmidt died in October 2004, and his family will accept the award on his behalf. Throughout Schmidt's career, which included positions in the legislative and executive branches, he strove to push the government toward greater openness and to change attitudes about access. The range of issues on which he worked included the 1974 Freedom of Information Act, the "Official Secrets Act" of 2000, and, most recently, provisions of the USA PATRIOT Act.

The Madison Award is presented each year by ALA on the anniversary of James Madison's birth to honor those who have championed, protected, and promoted public access to government information and the public's right to know.

This year, ALA also presented the inaugural Eileen Cooke State and Local Madison Award to the Minnesota Coalition on Government Information. The award, named for noted ALA Executive Director Eileen Cooke and for President James Madison, honors those at state and local levels who have championed, protected, and promoted public access to government information and the public's right to know.

In the late 1980s, building on the work of Cooke-a Minnesota native-a number of advocates in Minnesota determined to address the challenges to access to government information at the state and local levels. They established the Minnesota Coalition on Government Information, which represents a diverse network of individuals and agencies committed to access in the fullest sense and to the role of the state as producer, collector, regulator and provider of access. The coalition includes state agencies, librarians and libraries, representatives of the press, computer professionals, information providers, archivists, and others who care about the issues surrounding access to government information. $n$ 